\title{
Pembagian Masker dan Vitamin C dalam Upaya Pencegahan Penularan COVID-19 pada Pedagang di Pasar Oesao-Kabupaten Kupang
}

\author{
Arman Rifat Lette ${ }^{1}$, Vinsensius Belawa Lemaking ${ }^{2}$, Fepyani Thresna Feoh ${ }^{3}$, \\ Istha Leanni Muskananfola ${ }^{4}$, Jannes Bastian Selly ${ }^{5}$, Maryati Agustina Barimbing ${ }^{6}$, \\ Rosina Kardina Kidi Hurek ${ }^{7}$, Yohannes Dion ${ }^{8}$ \\ Universitas Citra Bangsa, Jln. Manafe No.17, Kelurahan Kayu Putih, Kota Kupang, Nusa Tenggara \\ Timur. 85111 \\ Email: lette.arman@gmail.com ${ }^{1}$
}

\begin{abstract}
ABSTRAK
Coronavirus Disease 2019 (COVID-19) adalah penyakit jenis baru yang belum pernah diidentifikasi sebelumnya pada manusia dan menyebabkan gangguan pada saluran pernapasan manusia. Pasar menjadi salah satu tempat yang berpotensial terjadinya penularan COVID-19. Sudah banyak kasus penularan COVID-19 yang terjadi di dalam pasar yang ada di Indonesia Tujuan pengabdian masyarakat adalah untuk mengedukasi para pedagang untuk melakukan upaya pencegahan COVID-19. Metode pengabdian yang dilakukan adalah pembagian masker dan vitamin C serta edukasi tentang pencegahan COVID-19 kepada para pedagang yang berjualan di pasar Oesao. Kegiatan pengabdian masyarakat ini dilaksanakan pada hari sabtu tanggal 09 Mei 2020 pukul 10.00-12.00 WITA. Kegiatan pengabdian ini dilaksanakan di pasar OesaoKabupaten Kupang. Total masker dan vitamin yang dibagikan sebanyak 450 paket. Kegiatan pengabdian dapat berjalan dengan baik. Pihak pengelola dan kepolisian setempat mendukung kegiatan pengabdian yang dilakukan. Para pedagang mulai sadar dan memakai masker setelah kegiatan pengabdian ini dilakukan walaupun belum semua pedagang menjadi sadar. Komunikasi, Edukasi dan Informasi (KIE) perlu secara berkala diberikan kepada para pedagang karena kesadaran pedagang untuk mematuhi protokol Kesehatan cukup rendah.
\end{abstract}

Kata kunci: Masker; Vitamin C; COVID-19; Pedagang; Pasar

\section{ABSTRACT}

Coronavirus Disease 2019 (COVID-19) was a new type of disease that has never been previously identified in humans and causes human respiratory tract disorders. The market was one of the potential places for the transmission of COVID-19. There have been many cases of COVID-19 transmission that have occurred in markets in Indonesia. Community service aims to educated traders to make efforts to prevent COVID-19. The service method carried out was the distribution of masks and vitamin $C$ and education about the prevention of COVID-19 to traders selling in the Oesao market. This community service activity was held on Saturday, May 9, 2020, at 10.00-12.00 WITA. This service activity was carried out in the Oesao market, Kupang Regency. The total masks and vitamins distributed were 450 packages. Community service activities can go well. The management and local police support the service activities carried out. The traders began to realize and wear masks after this service activity, even though not all traders become aware. Communication, Education, and Information (IEC) need to be periodically provided to traders because the traders' awareness to comply with Health protocols is quite low.

Keywords: Mask; Vitamin C; COVID-19; Trader; Market 


\section{PENDAHULUAN}

Coronavirus Disease 2019 (COVID-19) adalah penyakit jenis baru yang belum pernah diidentifikasi sebelumnya pada manusia dan menyebabkan gangguan pada saluran pernapasan manusia. Virus corona adalah zoonosis (ditularkan antara hewan dan manusia), namun hewan yang menjadi sumber penularan COVID-19 ini masih belum diketahui dengan pasti (Kementerian Kesehatan RI, 2020). Awalnya, Diperkirakan bahwa pasien atau penderita yang terinfeksi Coronavirus di China mungkin telah mengunjungi pasar makanan laut di mana hewan hidup dijual. Selain itu diperkiran penderita tertular melalui hewan atau burung yang terinfeksi dan dijadikan sebagai sumber makanan. Namun selanjutnya investigasi mengungkapkan bahwa beberapa orang tertular infeksi bahkan tanpa catatan pernah mengunjungi pasar makanan laut (Shereen dkk., 2020). Pengamatan ini menunjukkan kemampuan penyebaran coronavirus dari manusia ke manusia, yang kemudian dilaporkan lebih dari 200 negara di dunia telah terinfeksi oleh coronavirus. Penyebaran Coronavirus antar manusia terus terjadi dan mengalami peningkatan. Coronavirus menyebabkan angka kematian/ mortalitas yang tinggi (Huang, 2020)

Data per tanggal 16 November 2020 menunjukkan bahwa jumlah kasus COVID-19 di Indonesia mencapai 470.648 orang, dirawat sebanyak 59.909 orang, dan yang meninggal mencapai 15.296 orang (Covid-19, 2020). Sementara Itu, Penderita penyakit COVID-19 klaster pasar tradisional masih terus bertambah. Data Ikatan Pedagang Pasar Indonesia (IKAPPI) mencatat jumlah kasus positif dari klaster pasar tradisional mencapai 1.172 kasus dan 37 di antaranya meninggal dunia. Korban yang terjangkit COVID-19 tersebar dari 201 pasar tradisional dan jumlahnya meningkat di 56 wilayah Indonesia sejak pertengahan Juni 2020 (Pusparisa, 2020).

COVID-19 dapat menyebar dari orang ke orang melalui percikan-percikan dari hidung atau mulut yang biasa disebut droplet. Droplet dapat menyebar keluar saat orang yang terjangkit COVID-19 batuk atau mengeluarkan napas. Droplet kemudian jatuh dan menempel dipermukaan benda di sekitar seperti : meja, pintu, kursi, kaca dan sebagainya. Jika Orang sehat menyentuh benda atau permukaan tersebut, lalu menyentuh mata, hidung atau mulutnya, maka orang tersebut dapat terjangkit COVID-19. Penularan COVID-19 juga dapat terjadi jika orang secara tidak sadar menghirup percikan yang keluar dari batuk atau napas orang yang terjangkit COVID-19 (UNICEF, 2020). Saat ini, pasien COVID-19 dan penderita tanpa gejala adalah sumber utama penularan di dalam masyarakat (Hoehl, Rabenau, Berger, 2020). 
Berbagai upaya pencegahan telah ditetapkan dan dihimbau oleh pemerintah untuk menekan laju penularan coronavirus, seperti : pemakaian masker, cuci tangan secara rutin, Jaga jarak/ physical distancing, etika batuk dan sebagainya. Salah satu kebijakan atau protokol Kesehatan yang harus dipatuhi masyarakat adalah menggunakan masker saat berada di luar rumah. Penggunaan maker terbukti efektif mencegah penularan COVID-19 di dalam masyarakat. Himbauan pencegahan berupa protokol-protokol kesehatan yang lain juga harus dilaksanakan dengan disiplin oleh masyarakat untuk memutus mata rantai penularan. Kedisiplinan masyarakat melakukan protokol Kesehatan menjadi sangat penting dalam mencegah penularan COVID-19.

Pasar menjadi salah satu tempat yang berpotensial terjadinya penularan COVID-19. Sudah banyak kasus penularan COVID-19 yang terjadi di dalam pasar dan menyebabkan kematian. Penularan COVID-19 di berbagai pasar tradisional terjadi akibat minimnya penerapan protokol kesehatan. kurangnya sosialisasi mengenai penyakit COVID-19, juga memicu pedagang untuk menolak mematuhi protocol kesehatan dan melakukan tes cepat untuk deteksi dini penyakit tersebut (Pusparisa, 2020).

Pasar Oesao terletak di kelurahan Oesao Kecamatan Kupang Timur, Kabupaten Kupang, Nusa Tenggara Timur. Berdasarkan observasi awal diketahui banyak lapak pedagang yang ditutup pada masa pandemi COVID-19 namun suasana di Pasar Oesao tetap ramai oleh penjual dan pembeli. Selain itu, banyak pedagang yang tidak melakukan protokol Kesehatan di pasar Oesao, khususnya penggunaan masker pada saat berjualan walaupun sebenarnya mereka telah memiliki masker. Hal ini dapat menyebabkan penularan COVID-19 di dalam pasar. Kurangnya pengetahuan dan kesadaran pedagang tentang pencegahan COVID-19 menjadi tantangan tersendiri dalam upaya memutus mata rantai penularan COVID-19 di dalam pasar.

\section{METODE}

Metode pengabdian yang dilakukan adalah pembagian masker dan vitamin $\mathrm{C}$ serta edukasi tentang pencegahan COVID-19 kepada para pedagang yang berjualan di pasar Oesao. Tim merupakan dosen dari Universitas Citra bangsa dan juga melibatkan sebanyak 10 mahasiswa/I Universitas Citra Bangsa. Tim juga melakukan koordinasi dengan pihak kepolisian setempat untuk mendukung kegiatan pengabdian masyartakat ini. Masker dan vitamin C yang dibagikan merupakan sumbangan dari kampus Universitas Citra Bangsa, dan juga sumbangan dari tim dosen. Kegiatan pengabdian masyarakat ini dilaksanakan 
pada hari Sabtu tanggal 09 Mei 2020 pukul 09.30-12.00 WITA. Kegiatan pengabdian ini dilaksanakan di Pasar Oesao, Kecamatan Kupang Timur, Kabupaten Kupang-Nusa Tenggara Timur. Selain kepada para pedagang, tim juga membagi masker dan vitamin $\mathrm{C}$ kepada tukang ojek yang ada disekitar pasar. Masker dan Vitamin C digabung dalam 1 plastik lalu dibagikan. Total masker dan vitamin $\mathrm{C}$ yang dibagikan adalah 450 paket.

\section{HASIL, PEMBAHASAN, DAN DAMPAK}

Penularan COVID-19 dari manusia ke manusia melalui kontak langsung dengan percikan dari saluran napas orang yang terinfeksi (yang keluar melalui batuk dan bersin). Orang juga dapat terinfeksi karena menyentuh permukaan yang terkontaminasi virus ini lalu menyentuh wajahnya (Misalnya mata, hidung, mulut) (UNICEF, 2020). Oleh karena itu penggunaan masker menjadi sangat efektif dalam mencegah penularan COVID-19, khususnya diantara para pedagang. Sebelum melakukan kegiatan pengabdian, tim terlebih dahulu berkoordinasi dengan pihak kepolisian setempat. Pihak kepolisian mendukung, mendampingi serta terlibat langsung dengan kegiatan pengabdian ini.
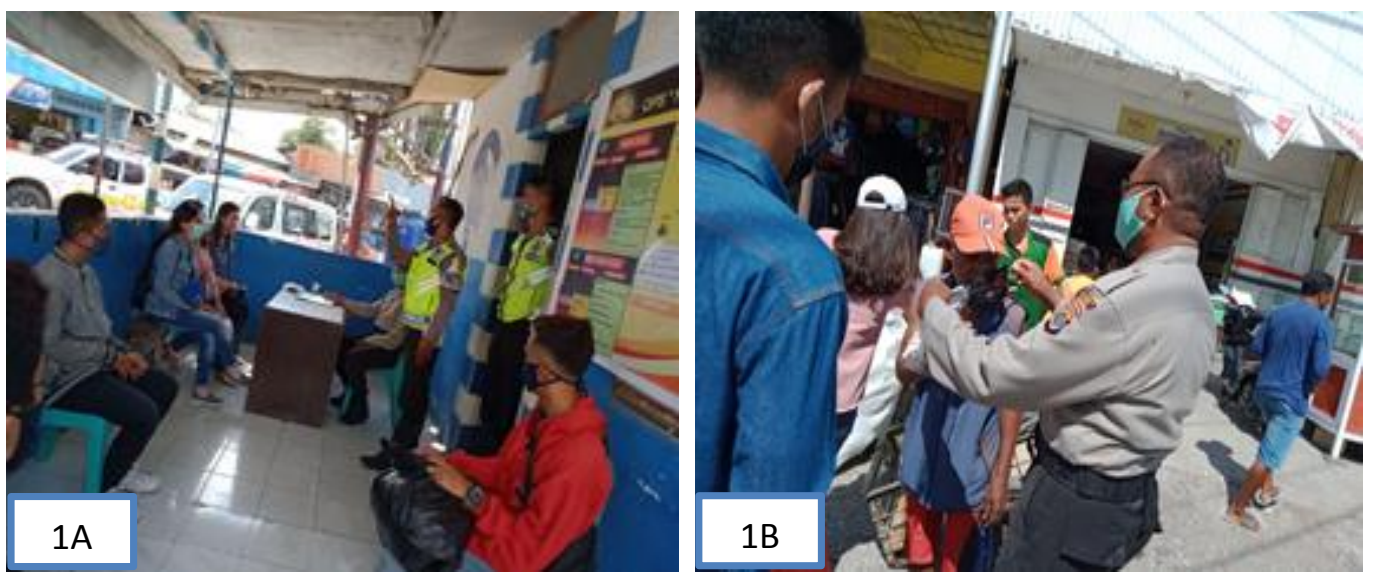

Gambar 1A Tim saat melakukan koordinasi dengan pihak kepolisian setempat dan Gambar 1B pihak kepolisian mendukung serta ikut terlibat dalam kegiatan pengabdian

Saat melakukan pengabdian ini, tim menemukan hampir sebagaian besar pedagang tidak menggunakan masker. Bahkan ada pedagang yang telah memiliki masker namun tidak digunakan selama berjualan. Sangat jelas terlihat bahwa kesadaran pedagang untuk mematuhi protokol Kesehatan masih cukup rendah. Ada pedagang yang menyatakan lupa membawa masker, dan menayatakan sesak nafas kalau terus memakai masker selama berjualan (Ferdiansyah, 2020). Pedagang masih menganggap biasa, dan menyikapi dengan santai masalah COVID-19. Tim pun Kembali mengedukasi dan mengingatkan pedagang untuk mematuhi protocol kesehatan, khususnya memakai masker selama berjualan. 


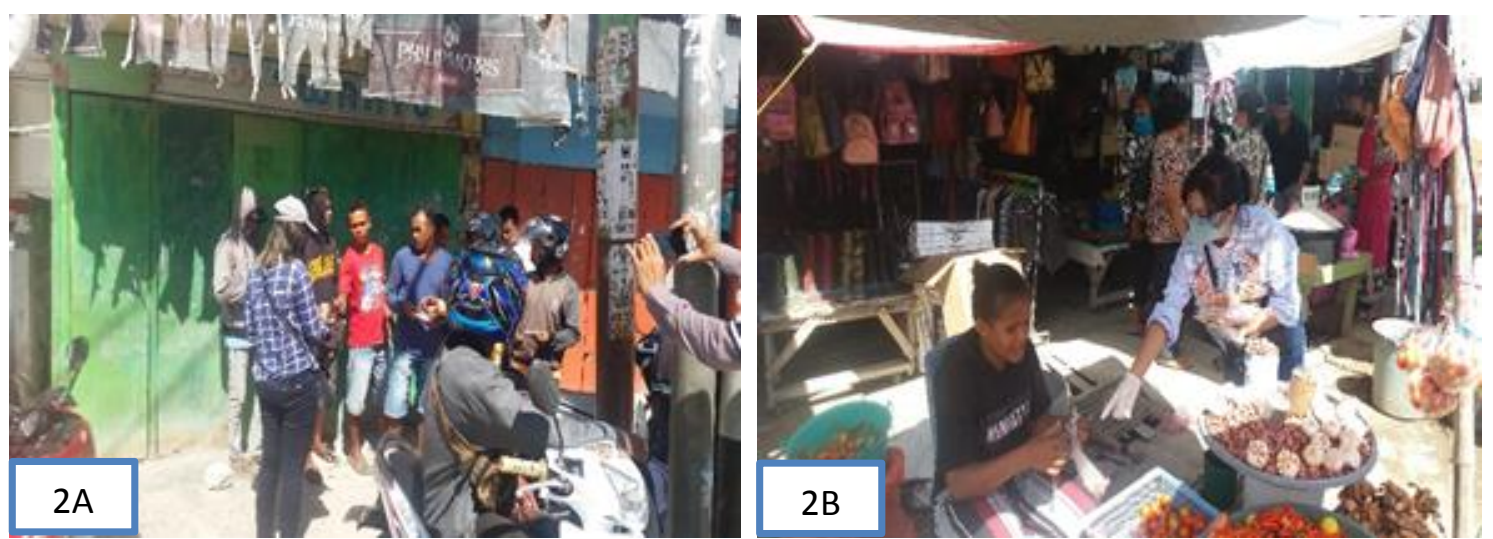

Gambar 2A tim membagikan masker dan vitamin C kepada tukang ojek dan Gambar 2B tim membagikan masker dan vitamin $\mathrm{C}$ kepada pedagang sayur

Selain menyasar dan membagikan masker dan vitamin $C$ di dalam pasar, tim juga membagikan masker kepada pedagang jagung dan kue cucur Oesao yang berjarak 200 meter dari pasar Oesao. Semua pedagang yang ditemui oleh tim menjadi sasaran dalam kegiatan ini, baik itu pedagang sayur, pedagang ayam dan telur, pedagang jagung, pedagang kue, pedagang pakaian dan pedagang di dalam kios/toko di wilayah pasar Oesao. Selain pedagang, tim juga menyasar para tukang ojek yang kedapatan tidak memakai masker saat sedang berada di pangkalan ojek yang berlokasi dekat dengan pasar Oesao.
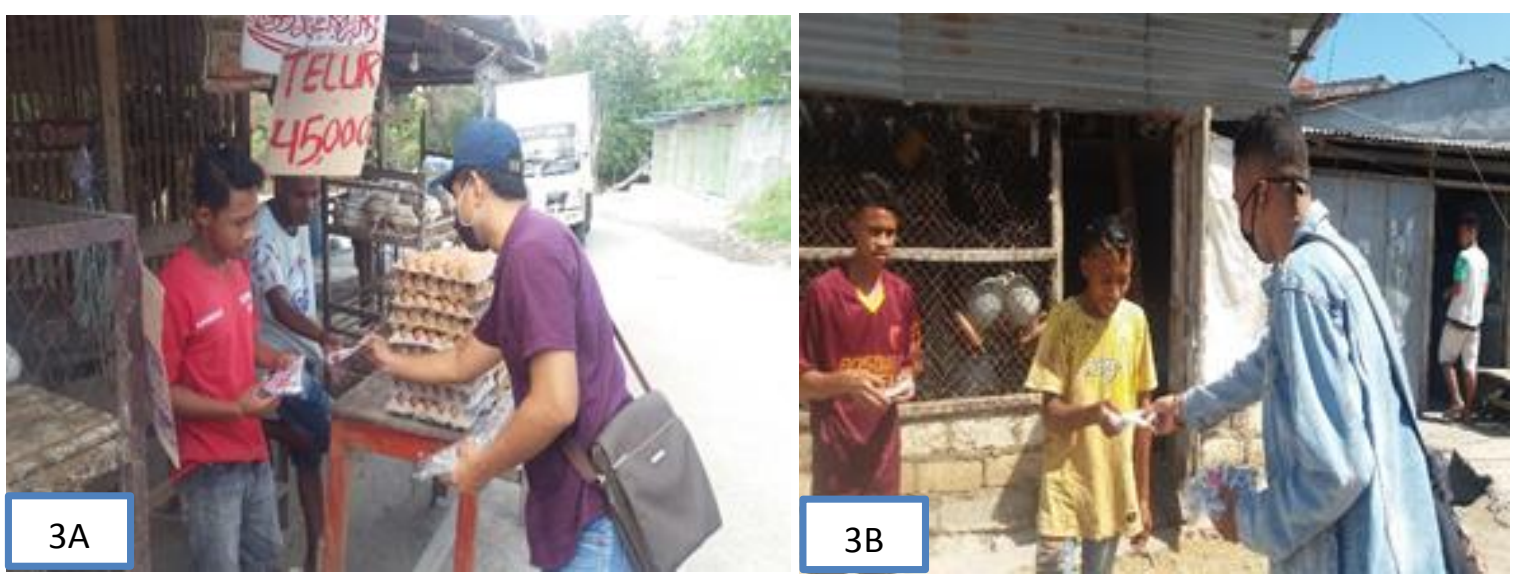

Gambar 3A dan Gambar 3B. Tim Membagikan Masker dan Vitamin C kepada Pedagang Telur dan Ayam

Edukasi juga diberikan kepada pedagang untuk mematuhi protokol-protokol kesehatan, seperti: memakai masker, mencuci tangan, menjaga jarak aman dan tidak bersentuhan dengan orang lain. Edukasi diberikan di sela-sela pembagian masker dan vitamin C. Saat membagikan masker disertai edukasi, ada pedagang yang langsung merespon dengan menggunakan masker yang telah diberikan. Hal ini menunjukkan bahwa pembagian masker dan vitamin $\mathrm{C}$ disertai edukasi terbukti cukup efektif meningkatkan kesadaran pedagang dalam upaya mencegah penularan COVID-19. Pihak kepolisian dan 
pedagang mengucapkan terima kasih dan merasa terbantu dengan kegiatan pengabdian yang dilakukan. Pada akhirnya, Kegiatan pengabdian ini dapat berjalan dengan baik.

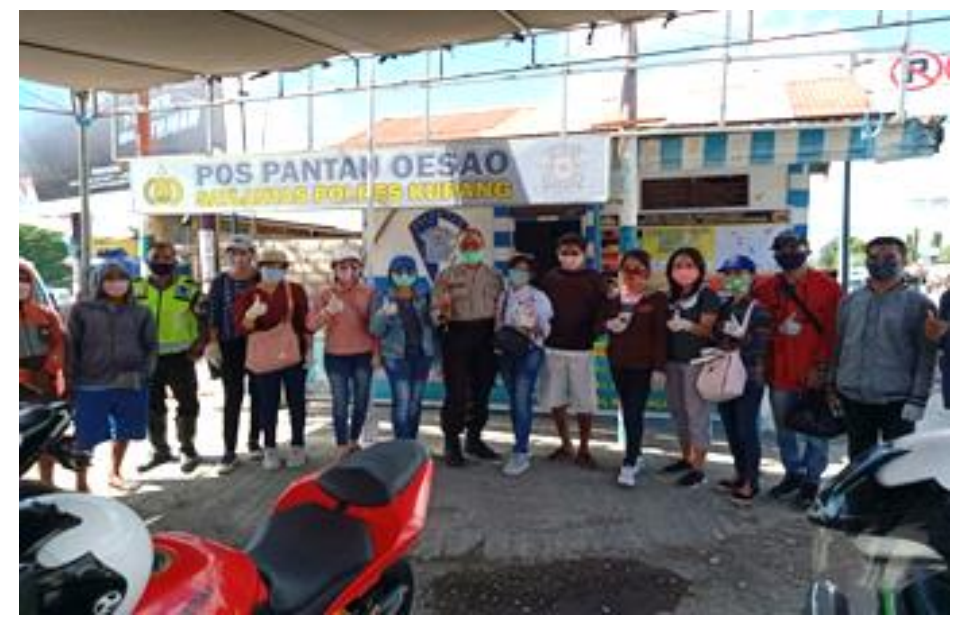

Gambar 4. Tim foto bersama dengan pihak kepolisian dan beberapa tukang ojek saat selesai kegiatan

Beberapa minggu setelah kegiatan pengabdian ini, tim melakukan evaluasi melalui observasi. Berdasarkan hasil evaluasi diketahui bahwa para pedagang mulai rajin menggunakan masker saat berjualan. Namun, belum semua pedagang sadar dan patuh menggunakan masker. Diketahui masih ada pedagang yang tidak memakai masker saat berjualan setelah kegiatan pengabdian ini dilakukan. Selain karena kurangnya kesadaran, salah satu hal yang mempengaruhi adalah keraguan masyarakat terhadap perubahan sosial khususnya kebijakan terkait pencegahan COVID-19 atau era new normal (memakai masker, jaga jarak, dan cuci tangan dengan rutin). Skeptisisme atau keraguan berhubungan dengan kepatuhan yang lebih rendah terhadap himbauan pemerintah (Brzezinski dkk., 2020).

\section{SIMPULAN}

Kegiatan pembagian masker dan vitamin $\mathrm{C}$ dapat berjalan dengan baik. Pihak Kampus dan kepolisian setempat juga mendukung kegiatsan ini. Para pedagang menerima dengan senang hati dan berterima kasih atas masker dan vitamin $\mathrm{C}$ yang telah dibagikan. Komunikasi, Edukasi dan Informasi (KIE) perlu secara berkala dilakukan kepada para pedagang di dalam pasar karena kesadaran pedagang untuk mematuhi protokol Kesehatan cukup rendah. 


\section{DAFTAR PUSTAKA}

Brzezinski, A., Kecht, V., Dijcke, D., \& Wright, A. . (2020). Belief in Science Influences Physical Distancing in Response to COVID-19 Lockdown Policies. Becker Fridmen Institute, 56, 1-17. https://ssrn.com/abstract=3587990

Covid-19, G. T. (2020). Situasi virus COVID-19 di Indonesia. Gugus Tugas Percepatan Penanganan Covid-19. https://covid19.go.id/

Ferdiansyah, R. (2020). Masyarakat masih Abaikan Protokol Kesehatan di Pasar. Media Indonesia. sumber: https://mediaindonesia.com/read/detail/321724-masyarakatmasih-abaikan-protokol-kesehatan-di-pasar

Hoehl, Rabenau, Berger, dkk. (2020). Evidence of SARS-CoV-2 Infection in Returning Travelers from Wuhan, China. $N$ Engl J Med, 382(13), 1278- 1280. https://doi.org/10.1056/NEJMc2001899

Huang, dkk. (2020). Clinical features of patients infected with 2019 novel coronavirus in Wuhan, China. Www.Thelancet.Com, 395, 497-506.

Kementerian Kesehatan RI. (2020). Pedoman pencegahan dan pengendalian Coronavirus Disease 2019 (Covid-19). Kementerian Kesehatan RI. https://covid19.go.id/p/protokol/pedoman-pencegahan-dan-pengendaliancoronavirus-disease-covid-19-revisi-ke-5

Pusparisa, Y. (2020). Penularan Covid-19 di Pasar Tradisional Tembus Seribu Kasus. Databoks. https://databoks.katadata.co.id/datapublish/2020/07/20/penularan-covid19-di-pasar-tradisional-tembus-seribu-kasus

Shereen, M. ., Khan, S., Kazmi, A., Bashir, N., \& Siddique, R. (2020). COVID-19 infection: Origin, transmission, and characteristics of human coronaviruses. Journal of Advanced Research, 24, 91-98.

UNICEF. (2020). Pesan dan Kegiatan Utama Pencegahan dan Pengendalian COVID-19 di Sekolah. UNICEF. https: // www.who.int/ docs/defaultsource/searo/indonesia/covid19/pesan-dan-kegiatan-utama- pencegahan-danpengendalian- covid- 19- di- sekolah--- indonesian--march-2020.pdf?sfvrsn= 5cdfea17_2 